\title{
Metrifonate Increases Neuronal Excitability in CA1 Pyramidal Neurons from Both Young and Aging Rabbit Hippocampus
}

\author{
M. Matthew Oh, ${ }^{1,2}$ John M. Power, ${ }^{1}$ Lucien T. Thompson, ${ }^{1,2}$ Pamela L. Moriearty, ${ }^{3}$ and John F. Disterhoft ${ }^{1,2}$ \\ ${ }^{1}$ Department of Cell and Molecular Biology and 2Institute for Neuroscience, Northwestern University Medical School, \\ Chicago, Illinois 60611-3008, and 'BDepartment of Psychiatry, Southern Illinois University Medical School, Springfield, \\ Illinois 62794
}

\begin{abstract}
The effects of metrifonate, a second generation cholinesterase inhibitor, were examined on CA1 pyramidal neurons from hippocampal slices of young and aging rabbits using currentclamp, intracellular recording techniques. Bath perfusion of metrifonate (10-200 $\mu \mathrm{m})$ dose-dependently decreased both postburst afterhyperpolarization (AHP) and spike frequency adaptation (accommodation) in neurons from young and aging rabbits (AHP: $p<0.002$, young; $p<0.050$, aging; accommodation: $p<0.024$, young; $p<0.001$, aging). These reductions were mediated by muscarinic cholinergic transmission, because they were blocked by addition of atropine $(1 \mu \mathrm{M})$ to the perfusate. The effects of chronic metrifonate treatment (12 $\mathrm{mg} / \mathrm{kg}$ for 3 weeks) on CA1 neurons of aging rabbits were also examined ex vivo. Neurons from aging rabbits chronically
\end{abstract}

The learning and cognitive deficits observed in normal aging and in Alzheimer's disease (AD) patients are hypothesized to be partly caused by the loss of cholinergic neurons in the basal forebrain. It has been suggested that these deficits may be alleviated by improving cholinergic function (Bartus et al., 1982; Hallak and Giacobini, 1989). Currently, tacrine and donepezil (United States) and exelon and galanthamine (Europe) are clinically approved cholinesterase inhibitors (ChEI) used for treating AD. Further research is ongoing to develop more effective ChEIs with fewer side effects (Cummings et al., 1998; Morris et al., 1998; Pettigrew et al., 1998).

One new generation ChEI currently in phase III clinical trials is metrifonate, an organophosphate compound that is considered to be a prodrug, because it is transformed nonenzymatically to 0,0-dimethyl 2,2-dichlorovinyl phosphate, which produces the long-lasting inhibition of both acetylcholinesterase (AChE) and butyrylcholinesterase (Nordgren et al., 1978; Schmidt et al., 1998). More importantly, extended treatment with metrifonate has been shown to result in an increased acetylcholine (ACh) level with fewer, less severe side effects than other ChEIs (Soininen et al., 1990; Becker et al., 1991; Sihver et al., 1997). Behavioral experiments have demonstrated that metrifonate treatment improved cognitive performance in $\mathrm{AD}$ patients (Cummings et

\footnotetext{
Received July 6, 1998; revised Dec. 9, 1998; accepted Dec. 11, 1998.

This work was supported by National Institutes of Health Grant AG08796 (J.F.D.) and Bayer Corporation. We thank Dr. Bernard Schmidt for helpful discussions.

Correspondence should be addressed to Dr. John F. Disterhoft, Department of Cell and Molecular Biology, Northwestern University Medical School, 303 East Chicago Avenue, Chicago, IL 60611-3008.

Dr. Thompson's present address: University of Texas at Dallas, Richardson, TX 75083.

Copyright (ㄷ) 1999 Society for Neuroscience $\quad 0270-6474 / 99 / 191814-10 \$ 05.00 / 0$
}

treated with metrifonate had significantly reduced spike frequency accommodation, compared with vehicle-treated rabbits. Chronic metrifonate treatment did not result in a desensitization to metrifonate ex vivo, because bath perfusion of metrifonate $(50 \mu \mathrm{M})$ significantly decreased the AHP and accommodation in neurons from both chronically metrifonateand vehicle-treated aging rabbits. We propose that the facilitating effect of chronic metrifonate treatment on acquisition of hippocampus-dependent tasks such as trace eyeblink conditioning by aging subjects may be caused by this increased excitability of CA1 pyramidal neurons.

Key words: afterhyperpolarization; aging; atropine; carbachol; cholinesterase inhibitor; eserine; hippocampal slice; metrifonate; rabbits; spike frequency adaptation al., 1998; Morris et al., 1998; Pettigrew et al., 1998), reduced both scopolamine- and basal forebrain lesion-induced deficits in water maze and passive avoidance tasks in rats (Itoh et al., 1997), and rescued object recognition in aging rats (Scali et al., 1997). Recently, our laboratory demonstrated that metrifonate treatment facilitated acquisition of trace (hippocampus-dependent) eyeblink conditioning in aging rabbits (Kronforst-Collins et al., 1997a,b).

Although there are numerous behavioral experimental reports concerning metrifonate, there is no electrophysiological literature concerning the effects of metrifonate, which may be relevant to the mechanism of actions mediating its potentially valuable therapeutic benefits. Several in vitro experiments have demonstrated that application of $\mathrm{ACh}$, muscarinic agonists, or anticholinesterases increased neuronal excitability [reduced postburst afterhyperpolarization (AHP) and spike frequency adaptation (accommodation)] of hippocampal pyramidal neurons (Bernardo and Prince, 1981, 1982; Cole and Nicoll, 1983, 1984a,b; Madison and Nicoll, 1984; Halliwell, 1990; Taylor and Griffith, 1993; Pedarzani and Storm, 1996). Furthermore, both the AHP and accommodation were reduced in CA1 neurons from young and aging rabbits that acquired eyeblink conditioning, but not in trained rabbits that did not learn (Disterhoft et al., 1986, 1988, 1996; Coulter et al., 1989; de Jonge et al., 1990; Moyer et al., 1996; Thompson et al., 1996b). Also, both the AHP and accommodation are greater in CA1 neurons from aging rabbits (Moyer et al., 1992) and rats (Landfield and Pitler, 1984; Potier et al., 1992) as compared with that from young animals.

The current study was designed to determine (1) the effects, (2) the effective concentrations of bath application of metrifonate on CA1 neurons from hippocampal slices of young and aging rabbits, 
(3) whether chronic metrifonate treatment in aging rabbits alters basal CA1 excitability ex vivo, and (4) if the chronic metrifonate treatment has a saturating, desensitizing effect.

\section{MATERIALS AND METHODS}

Subjects. Young ( $<3$ month) and aging ( $>36$ month) female New Zealand albino rabbits (Oryctolagus cuniculus) were used as subjects. We chose to study these two age groups for the following reasons: (1) previous work in our laboratory has established that rabbits, $30+$ months old, are impaired in acquiring the trace eyeblink conditioning task (Thompson et al., 1996a), and similar impairments have been observed in aging humans (Woodruff-Pak and Thompson, 1988); (2) we have demonstrated that hippocampal pyramidal neurons from aging rabbits are less excitable than those from young animals and possibly contribute to the age-related learning deficits (see results; Moyer et al., 1992); (3) the effects of bath application of metrifonate in vitro have not been explored in either age group; and (4) previous work has demonstrated that metrifonate in vivo unequally increased the ACh levels in the hippocampus of young and aging subjects (Scali et al., 1997), thus, bath application of metrifonate in vitro may also yield unequal effects on the hippocampal slices from young and aging subjects. Each subject was housed in an individual cage in a climate-controlled room on a $12 \mathrm{hr}$ light/dark cycle with ad libitum access to food and water. The animal care was provided and managed by the animal care personnel of Northwestern University after the guidelines established by the university and the United States Department of Agriculture.

Slice preparation. Hippocampal slices were made using procedures previously described (Moyer et al., 1996; Thompson et al., 1996b). The rabbits were anesthetized with halothane in a fume hood and killed by decapitation. The brain was quickly exposed, hemisected in situ, removed, and immersed in an ice-cold $\left(<1^{\circ} \mathrm{C}\right)$ oxygenated sucroseartificial CSF (aCSF) that minimizes anoxic impact during slice preparation (Aghajanian and Rasmussen, 1989) (sucrose-aCSF composition in mM: 248 sucrose, $26 \mathrm{NaHCO}_{3}, 10 \mathrm{D}$-glucose, $3 \mathrm{KCl}, 2.4 \mathrm{CaCl}_{2}, 1.3$ $\mathrm{MgSO}_{4}$, and $1.24 \mathrm{NaH}_{2} \mathrm{PO}_{4}$, gassed with $95 \% \mathrm{O}_{2}$ and $\left.5 \% \mathrm{CO}_{2}, \mathrm{pH} 7.4\right)$. After $\sim 4 \mathrm{~min}$ in the ice-cold sucrose-aCSF, both hippocampi were dissected out, cut into two $5 \mathrm{~mm}$ transverse chunks, and glued to a small, chilled chamber that was filled with the ice-cold sucrose-aCSF. Slices $(400 \mu \mathrm{M})$ were cut using a vibratome and placed in a holding chamber filled with normal aCSF ( $124 \mathrm{~mm} \mathrm{NaCl}$ substituted for sucrose) at room temperature $\left(\sim 22^{\circ} \mathrm{C}\right)$ for at least 45 min before being individually transferred to the submersion chamber (Medical Systems, Greenvale, NY) for recording.

Electrophysiological recording and data analysis. Intracellular recordings were made from CA1 pyramidal neurons using an Axoclamp 2A amplifier (Axon Instruments, Foster City, CA) and previously published protocols (Moyer et al., 1996; Thompson et al., 1996b). Microelectrodes were made from a thin-walled capillary glass and filled with $3 \mathrm{M} \mathrm{KCl}$ (30-50 M $\Omega$ ). Slices were individually transferred to a submersion chamber and continuously perfused $(\sim 1.75 \mathrm{ml} / \mathrm{min})$ with oxygenated aCSF heated to $31^{\circ} \mathrm{C}$. A cell was classified as a CA1 neuron and included in the study if it had little spontaneous activity at rest, a stable resting membrane potential less than $-60 \mathrm{mV}$, an action potential duration $>1.2$ msec from rise threshold to recrossing the resting potential, an input resistance $\geq 20 \mathrm{M} \Omega$, and an action potential amplitude $>80 \mathrm{mV}$ from rest. After the neuron had stabilized for $5 \mathrm{~min}$ after the initial impalement, the biophysical membrane properties were measured with the neuron held near $-68 \mathrm{mV}$ (using less than $\pm 0.2 \mathrm{nA}$ ) to ensure that the differences observed were not caused by voltage-dependent membrane properties.

The baseline membrane properties were measured in normal aCSF. The current-voltage $(I-V)$ relations were studied by using $400 \mathrm{msec}$ current steps (range, -1.0 to $+0.2 \mathrm{nA}$ ). The input resistance was calculated by measuring the plateau voltage deflection during the last $75 \mathrm{msec}$ of a $400 \mathrm{msec},-0.2 \mathrm{nA}$ hyperpolarizing step. The AHP was studied using a $100 \mathrm{msec}$ depolarizing current step that reliably elicited a burst of four action potentials. The duration of the AHP was measured as the time required for the membrane potential to return to the baseline potential for at least $10 \mathrm{msec}$ from the $100 \mathrm{msec}$ depolarizing current step offset. The peak AHP amplitude was calculated as the maximum negative voltage deflection from the baseline potential during the first $250 \mathrm{msec}$ after the current offset. The integrated area of the AHP was calculated from the current offset for the entire duration of the AHP. A total of five AHP measurements were made from each neuron at $30 \mathrm{sec}$ intervals.
Accommodation was studied using an $800 \mathrm{msec}$ depolarizing current step of the same stimulus intensity used to evoke the AHP. The number of action potentials elicited was noted for three trials at $30 \mathrm{sec}$ intervals.

After the baseline measurements were recorded, the perfusate was changed to an aCSF containing carbachol (500-1000 nM), eserine (500$5000 \mathrm{nM})$, metrifonate $(1-200 \mu \mathrm{M})$, atropine (1 $\mu \mathrm{M}$; by itself or added to the previously mentioned drugs), or vehicle (normal aCSF). The experimenter was blind to the identity of the perfusate until the end of data collection. The neuron was held near $-75 \mathrm{mV}$ (or at rest, if the resting membrane potential was less than $-75 \mathrm{mV}$ ) for $10 \mathrm{~min}$ and allowed to stabilize during the changing of the perfusate. After the $10 \mathrm{~min}$ interval, the biophysical measurements were repeated. In some cases, the neuron was subject to another perfusate, or a wash-out of the perfusate was attempted (blind procedures were used). At the end of the experiment, the resting membrane potential was determined as the difference in the potential before and after the microelectrode withdrawal from the neuron. The slice was changed if a cell was lost during an experiment, if more than five penetrating attempts were made, or after the completion of the experiment.

All data were digitized and analyzed on-line using a Lab NB or NB-MIO-16H and DMA-2800 boards (National Instruments, Austin, TX) interfaced to Power Macintosh computers using custom software routines written in LabView (National Instruments). Analog-to-digital sampling rates were $10 \mathrm{kHz}$ for $I-V$, AHP, and accommodation measurements and $1-2 \mathrm{kHz}$ for the resting membrane potentials. Complete analyses were performed off-line using procedures developed with LabView. Statistical analyses were performed using paired $t$ tests and ANOVA (StatView; Abacus Concepts, Berkeley, CA). Significant main effects were evaluated using Scheffe's post hoc tests. All data are reported as the mean \pm SEM.

Chronic treatment with metrifonate. Using similar procedures to those previously published (Kronforst-Collins et al., 1997b), aging ( $>40$ month) rabbits received 15 oral doses $(5 \mathrm{~d}$ of treatment followed by $2 \mathrm{~d}$ of no treatment repeated for three weeks) of either $12 \mathrm{mg} / \mathrm{kg}$ metrifonate dissolved in a $100 \mathrm{~mm}$ sodium citrate vehicle $(n=4$; mean age, $41.31 \pm$ 0.06 months) or vehicle alone ( $n=3$; mean age, $41.00 \pm 0.13$ months). Previously, $12 \mathrm{mg} / \mathrm{kg}$ metrifonate was found to produce optimum facilitation of trace eyeblink conditioning in aging rabbits (Kronforst-Collins et al., 1997a,b). Blood samples were taken from all subjects $1 \mathrm{~d}$ before the start of treatment and $\sim 2 \mathrm{hr}$ before killing. Twenty-four hours after the last treatment, hippocampal slices were prepared, and CA1 neurons were recorded from as described above. AHP, accommodation, and input resistance were measured sequentially as described above in aCSF, aCSF with $50 \mu \mathrm{M}$ metrifonate, and aCSF with $50 \mu \mathrm{M}$ metrifonate plus $1 \mu \mathrm{M}$ atropine perfusates with 10 min intervals between changes in the perfusate. The experimenter was blind to the identity of the chronic treatment during the daily administration, blood sampling, electrophysiological recordings, and data reduction until the end of the experiment.

ChE inhibition measurement. The level of ChE inhibition was measured using procedures described by Kronforst-Collins et al. (1997a,b). The subjects were given fentanyl citrate and droperidol anesthesia $(0.5 \mathrm{ml} / \mathrm{kg}$, i.m.) before blood sampling. Each blood sample was collected in two 1.5 $\mathrm{ml}$ aliquot tubes each containing $50 \mu \mathrm{l}$ of heparin. The samples were centrifuged at $1000 \times g, 4^{\circ} \mathrm{C}$ for $15 \mathrm{~min}$. The plasma and red blood cells (RBCs) were separated and stored at $-80^{\circ} \mathrm{C}$ until $\mathrm{ChE}$ inhibition assays were performed. It has been previously demonstrated that the level of $\mathrm{RBC} \mathrm{AChE}$ activity in the rabbit is significantly correlated with that of the ChE of the brain (Kronforst-Collins et al., 1997a). Thus, the mean percentages of ChE inhibition values were calculated for the RBCs for each subject. The ChE inhibition values were analyzed with ANOVA and unpaired $t$ tests.

Drugs. Metrifonate was a gift from Bayer Corporation (West Haven, CT). All other drugs used were purchased from Sigma (St. Louis, MO). Eserine and atropine stocks were made and used in near darkness. Stock solution of metrifonate $(\mathrm{pH} \sim 4.0)$ was prepared weekly and refrigerated $\left(\sim 3^{\circ} \mathrm{C}\right)$ along with the other stock solutions.

\section{RESULTS}

\section{Metrifonate decreased the AHP amplitude and area}

Metrifonate significantly decreased the AHP peak amplitude and integrated area in CA1 neurons from both young and aging subjects (Figs. 1D, 2A; Table 1). Significant reductions of the AHP amplitude and area were produced with $10 \mu \mathrm{M}$ metrifonate in the neurons from young rabbits $(p<0.006$; $p<0.046$, respec- 
Figure 1. Bath application of metrifonate significantly decreased the accommodation and the postburst AHP in CA1 neurons from aging subjects. An example of the effect of metrifonate on accommodation is illustrated in $A-C$ (same neuron). $A$ depicts a typical response elicited during the $800 \mathrm{msec}$ depolarizing pulse obtained in baseline measures. $B$ illustrates a typical increase in number of action potentials elicited during the accommodation pulse after the perfusate has been changed to $200 \mu \mathrm{M}$ metrifonate. $C$ depicts a typical decrease in the number of action potentials elicited after the perfusate has been changed to a combination of $200 \mu \mathrm{M}$ metrifonate and $1 \mu \mathrm{M}$ atropine, indicating that the metrifonate effect is muscarinic. An example of the AHP decrement observed after the perfusate has been changed to a $100 \mu \mathrm{M}$ metrifonate in CA1 neurons from aging subjects is illustrated in $D$ (scales for $B$ and $C$ are the same as that of $A$ ).
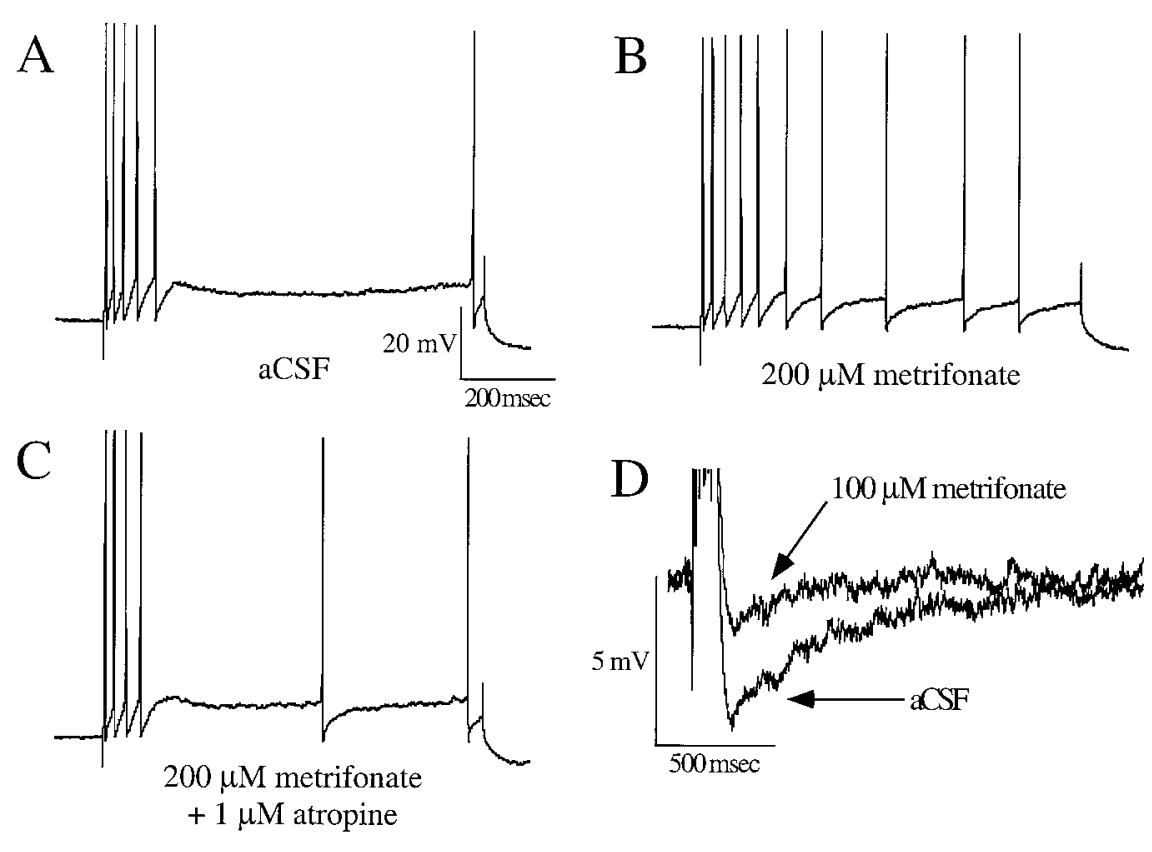

tively). No depression was observed in the neurons from aging rabbits at this concentration ( $p>0.309 ; p>0.178$, respectively). Instead, a significant reduction of the AHP amplitude was observed with $50 \mu \mathrm{M}$ metrifonate in the neurons from aging rabbits $(p<0.009)$; the AHP area was not significantly reduced, although a trend toward the reduction was observed $(p<0.074)$. Decrements in both AHP peak amplitude and integrated area for the neurons from aging rabbits were observed with $100 \mu \mathrm{M}$ metrifonate ( $p<0.002 ; p<0.001$, respectively). The neurons from young rabbits depolarized to levels at which regular bursts of spontaneous action potentials made the biophysical measurements impossible at $100 \mu \mathrm{M}$ metrifonate, and eventual cell death occurred in all but one of five neurons attempted. No such effects were observed in neurons from aging rabbits (tested up to $200 \mu \mathrm{M}$ ).

Metrifonate reduced the AHP peak amplitude in the neurons from both young and aging rabbits in a dose-dependent manner $\left(F_{(4,20)}=6.048, p<0.002 ; F_{(3,31)}=2.920, p<0.050\right.$; respectively). Scheffe's post hoc test revealed that the percent AHP peak amplitude reduction was significantly greater at both 50 and 100 $\mu \mathrm{M}$ metrifonate compared with $1 \mu \mathrm{M}$ in the neurons from young rabbits ( $p<0.019 ; p<0.026$, respectively). Also, ANOVA revealed that there was a significant difference in the mean baseline AHP peak amplitudes between the neurons from young (3.76 $\pm 0.33 ; n=25)$ and aging $(4.90 \pm 0.30, n=37)$ rabbits $\left(F_{(1,60)}=6.29 ; p<0.015\right)$ (Moyer et al., 1992).

Metrifonate also shortened the duration of the AHP. However, this effect was significant only at 100 and $200 \mu \mathrm{M}$ metrifonate for neurons from the aging rabbits $(p<0.001 ; p<0.025$, respectively).

\section{Metrifonate decreased spike frequency accommodation}

Metrifonate significantly decreased the accommodation of CA1 neurons from both young and aging rabbits (Figs. 1, 2B; Table 1). In neurons from the young rabbits, significant accommodation decrement was observed at $50 \mu \mathrm{M}$ metrifonate $(p<0.001)$. Lower concentrations of metrifonate were not effective; a higher concentration (100 $\mu \mathrm{M}$ tested) caused instability and cell death in neurons from young animals. In neurons from the aging rabbits,
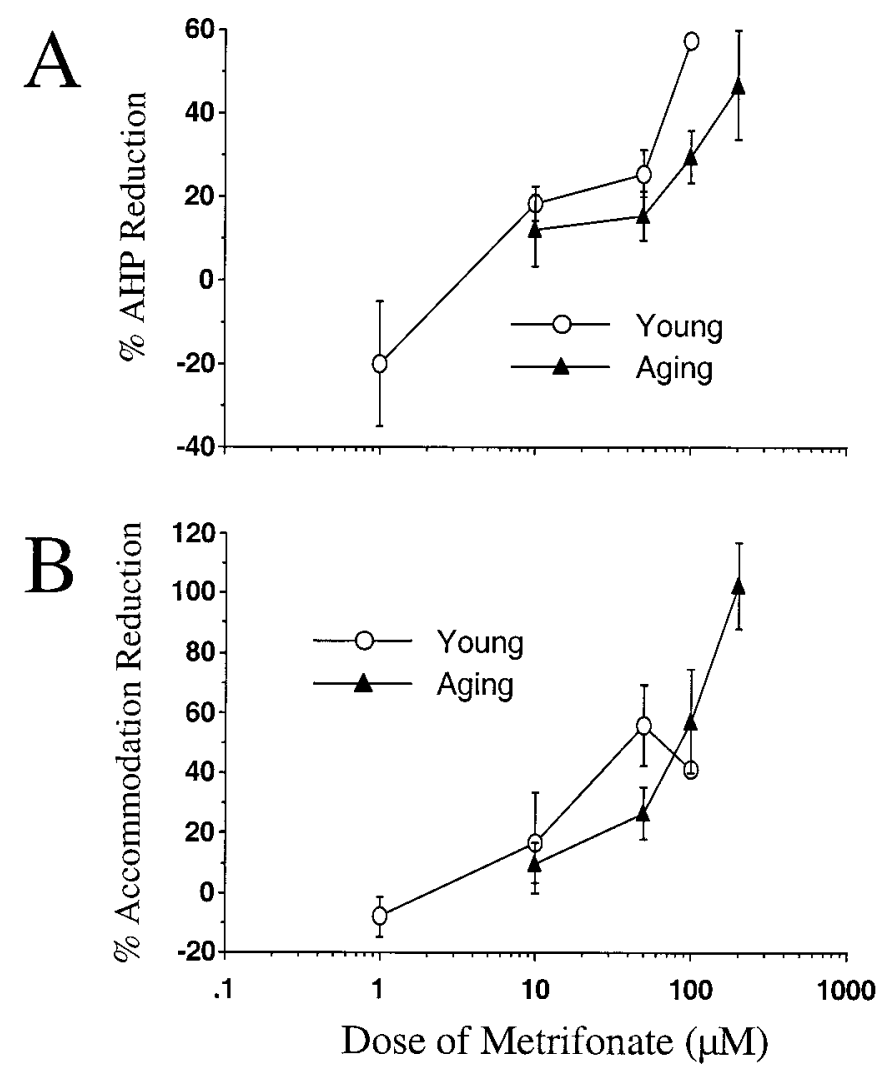

Figure 2. Bath application of metrifonate significantly increased neuronal excitability in CA1 neurons from both naive young and aging subjects. $A$, Mean percent AHP peak amplitude reduction from baseline after perfusion with metrifonate at various concentrations for both age groups is illustrated. In $B$, the mean percent change in number of action potentials elicited during the accommodation pulse from baseline after perfusion with metrifonate at various concentrations for both age groups are illustrated (mean \pm SEM). 
Table 1. Biophysical properties of CA1 neurons from young and aging rabbits after bath application of metrifonate in vitro

\begin{tabular}{|c|c|c|c|c|c|c|c|c|c|c|}
\hline & \multicolumn{3}{|c|}{ Metrifonate $(10 \mu \mathrm{M})$} & \multicolumn{3}{|c|}{ Metrifonate $(50 \mu \mathrm{M})$} & \multicolumn{4}{|c|}{ Metrifonate $(100 \mu \mathrm{M})$} \\
\hline & Baseline & Postdrug & $p$ value & Baseline & Postdrug & $p$ value & Baseline & Postdrug & $p$ value & \\
\hline \multicolumn{11}{|l|}{ Young } \\
\hline \multicolumn{11}{|l|}{ Postburst AHP } \\
\hline Amplitude (mV) & $-3.62 \pm 0.68$ & $-3.07 \pm 0.72$ & $0.006(6)$ & $-4.33 \pm 0.55$ & $-3.04 \pm 0.33$ & $0.007(11)$ & -2.04 & -0.87 & & (1) \\
\hline Area (mVsec) & $-3.09 \pm 1.31$ & $-2.01 \pm 0.98$ & $0.046(6)$ & $-3.69 \pm 1.15$ & $-1.91 \pm 0.77$ & $0.043(11)$ & -0.50 & -0.03 & & (1) \\
\hline Duration (sec) & $1.80 \pm 0.54$ & $1.44 \pm 0.38$ & $0.202(6)$ & $1.96 \pm 0.44$ & $1.54 \pm 0.53$ & $0.288(11)$ & 0.62 & 0.08 & & (1) \\
\hline Accommodation & $10.75 \pm 1.64$ & $11.62 \pm 1.33$ & $0.439(6)$ & $8.18 \pm 0.81$ & $12.73 \pm 1.44$ & $0.001(11)$ & 8.50 & 12.00 & & (1) \\
\hline \multirow[t]{2}{*}{ Input resistance $(\mathrm{M} \Omega)$} & $43.04 \pm 4.80$ & $39.65 \pm 5.09$ & $0.299(6)$ & $56.29 \pm 6.15$ & $52.28 \pm 4.35$ & $0.370(11)$ & 40.28 & 41.97 & & (1) \\
\hline & \multicolumn{3}{|c|}{ Metrifonate $(50 \mu \mathrm{M})$} & \multicolumn{3}{|c|}{ Metrifonate $(100 \mu \mathrm{M})$} & \multicolumn{4}{|c|}{ Metrifonate $(200 \mu \mathrm{M})$} \\
\hline \multicolumn{11}{|l|}{ Aging } \\
\hline \multicolumn{11}{|l|}{ Postburst AHP } \\
\hline Amplitude (mV) & $-4.94 \pm 0.47$ & $-4.12 \pm 0.46$ & 0.009 (17) & $-5.37 \pm 0.63$ & $-3.92 \pm 0.70$ & $0.002(9)$ & $-4.58 \pm 0.72$ & $-2.83 \pm 1.08$ & 0.028 & (5) \\
\hline Area (mVsec) & $-5.43 \pm 1.06$ & $-4.16 \pm 0.84$ & $0.074(17)$ & $-5.98 \pm 1.25$ & $-2.57 \pm 0.93$ & $0.001(9)$ & $-4.25 \pm 1.60$ & $-1.87 \pm 1.55$ & 0.012 & (5) \\
\hline Duration (sec) & $3.46 \pm 0.34$ & $3.34 \pm 0.44$ & $0.775(17)$ & $3.87 \pm 0.45$ & $1.46 \pm 0.26$ & $0.001(9)$ & $2.84 \pm 0.70$ & $0.89 \pm 0.38$ & 0.025 & (5) \\
\hline Accommodation & $7.02 \pm 0.56$ & $8.81 \pm 0.91$ & $0.014(17)$ & $5.89 \pm 0.66$ & $9.73 \pm 1.68$ & $0.020(8)$ & $6.75 \pm 0.52$ & $13.50 \pm 1.02$ & 0.0001 & (7) \\
\hline Input resistance $(\mathrm{M} \Omega)$ & $43.53 \pm 2.54$ & $47.53 \pm 2.31$ & $0.034(16)$ & $37.14 \pm 2.30$ & $37.43 \pm 3.77$ & $0.849(8)$ & $43.62 \pm 6.88$ & $40.68 \pm 3.55$ & 0.454 & (7) \\
\hline
\end{tabular}

The number in parentheses indicates the number of cells recorded. The data for young rabbits at $100 \mu \mathrm{M}$ metrifonate is based on the one of five neurons that survived through the drug application. The numbers in bold type indicate statistical significance using paired $t$ test. The measurements are the mean \pm SEM.

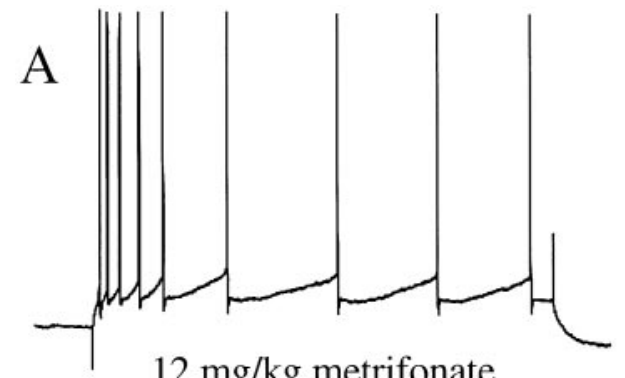

$12 \mathrm{mg} / \mathrm{kg}$ metrifonate

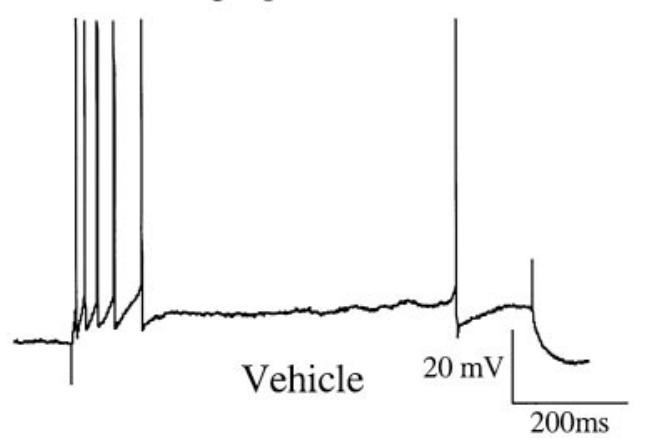

B

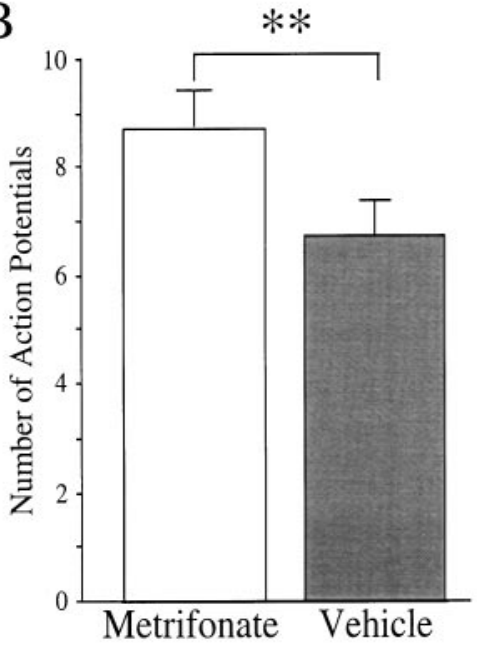

Figure 3. Chronic, oral treatment with metrifonate $(12 \mathrm{mg} / \mathrm{kg}$ daily) in aging subjects significantly reduced the accommodation in CA1 neurons. $A$ depicts a typical example of the differing response to an 800 msec depolarizing current pulse used to obtain four action potentials in the first $100 \mathrm{msec}$ observed in CA1 neurons from chronically metrifonate- (top) or vehicle-treated (bottom) subjects. $B$, Mean baseline accommodation was significantly reduced in neurons from the chronic metrifonate-treated subjects as compared with those from vehicle-treated subjects (mean $\pm \mathrm{SEM} ; * * p<0.01$, unpaired $t$ test). significant reductions were observed at concentrations of $50 \mu \mathrm{M}$ and higher metrifonate (Table 1). The accommodation decrement was dose-dependent in neurons from the aging rabbits $\left(F_{(3,32)}=7.11 ; p<0.001\right)$ with greater reduction observed at 200 $\mu \mathrm{M}$ compared with 10 and $50 \mu \mathrm{M}$ metrifonate $(p<0.035 ; p<$ 0.013 , respectively). A significant dose interaction was also observed for the neurons from young rabbits $\left(F_{(4,20)}=3.57 ; p<\right.$ $0.024)$. Finally, there was a significant difference of mean baseline accommodation measures between the neurons from young and aging rabbits $\left(F_{(1,60)}=10.60 ; p<0.002\right)$ (Moyer et al., 1992).

\section{Atropine partially reversed the effects of metrifonate}

Atropine, by itself, had no significant effect on the biophysical measurements (see Table 3$)$. Atropine $(1 \mu \mathrm{M})$ significantly re- versed the action of metrifonate on accommodation (Fig. 1; see Fig. 4). In the neurons from young rabbits, when atropine was added to $50 \mu \mathrm{M}$ metrifonate, the accommodation was returned to that observed during baseline $(p<0.028)$. However, atropine did not return the AHP measures back to baseline $(p>0.192)$.

\section{Chronic metrifonate treatment increased neuronal excitability}

CA1 neurons from chronically metrifonate-treated rabbits were more excitable than those from the vehicle-treated rabbits (Fig. 3). Typically, the neurons from aging rabbits exhibit a strong accommodation, as illustrated in Figure $1 A$ (see also Fig. $3 A$, bottom panel; Table 1). The baseline accommodation measurement was significantly reduced in neurons from the metrifonate- 

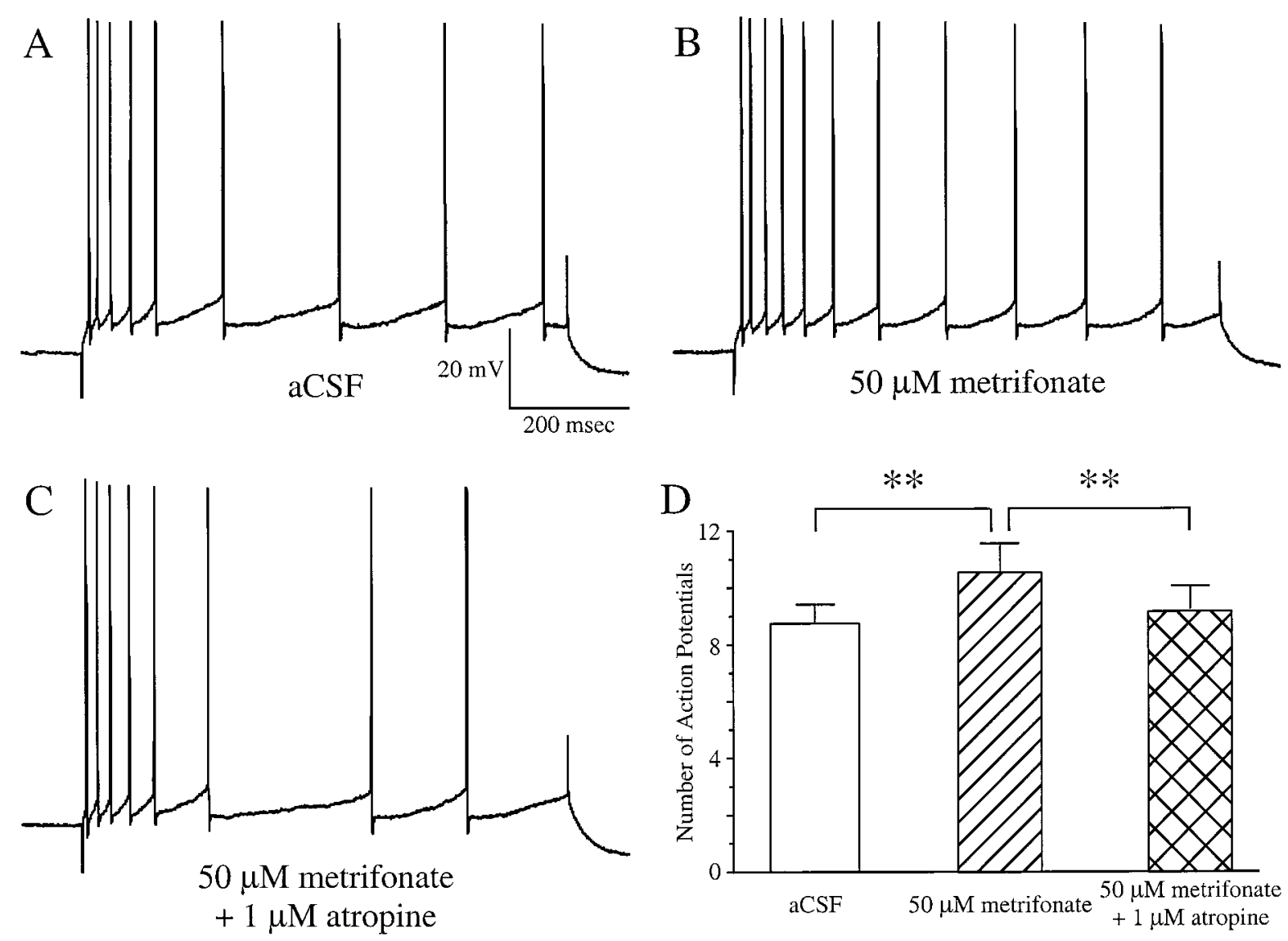

Figure 4. Bath application of $50 \mu \mathrm{M}$ metrifonate to CA1 neurons from chronic metrifonate-treated subjects further significantly decreased the accommodation $(B)$. This effect was significantly reversed by adding $1 \mu \mathrm{M}$ atropine to the perfusate $(C)$ (same neuron in $A-C$ ). The mean increase (with $50 \mu \mathrm{M}$ metrifonate) and decrease (with $50 \mu \mathrm{M}$ metrifonate and $1 \mu \mathrm{M}$ atropine) in the number of action potentials elicited in CA1 neurons from the chronic metrifonate-treated subjects are illustrated in $D$ (mean $\pm \mathrm{SEM} ; *^{* *} p<0.01$; paired $t$ tests).

treated aging rabbits $\left(F_{(1,45)}=9.789 ; p<0.003\right)$. The decreased accommodation brought the baseline accommodation measurements of these neurons to values similar to those from young, untreated subjects; $8.76 \pm 0.71$ action potentials vs $8.73 \pm 0.33$ action potentials for the aging, treated and young, untreated rabbits, respectively $\left(F_{(1,102)}=0.0019 ; p>0.965\right)$. The baseline AHP measurements were not significantly different between the metrifonate- and vehicle-treated aging rabbits $\left(F_{(1,45)}=0.358\right.$; $p>0.553)$.

The CA1 neurons from chronically metrifonate-treated aging rabbits were not desensitized to the effects of bath application of metrifonate ex vivo. Addition of metrifonate $(50 \mu \mathrm{M})$ to the perfusate significantly decreased the AHP peak amplitude and accommodation in neurons from both chronically metrifonate( $p<0.004 ; p<0.009$, respectively) and vehicle-treated rabbits ( $p<0.012 ; p<0.011$, respectively) (Figs. 4, 5; Table 2). The integrated area of the AHP was significantly reduced for the neurons from metrifonate-treated rabbits $(p<0.033)$. The decrements were reversed with $1 \mu \mathrm{M}$ atropine in the perfusate $(p<$ 0.028 for AHP; $p<0.033$ for accommodation; and $p<0.033$ for area; Figs. 4, 5; Table 2).

\section{Chronic metrifonate treatment reduced cholinesterase activity}

The chronic metrifonate treatment significantly decreased the RBC AChE activity of aging rabbits by $25 \%(24.62 \pm 3.62 \% ; n=$ $4 ; p<0.021)$; no inhibition of AChE activity was observed in the vehicle-treated, control subjects ( $p>0.241 ; n=3)$. The RBC AChE activity was significantly different between the two treatment groups $\left(F_{(1,5)}=28.79 ; p=0.003\right)$.

\section{Carbachol increased neuronal excitability}

Bath application of carbachol significantly increased the excitability of CA1 neurons from both young and aging subjects, as reported previously (Bernardo and Prince, 1982; Cole and Nicoll, 1983, 1984a,b; Potier et al., 1992; Taylor and Griffith, 1993; Pedarzani and Storm, 1996). At $500 \mathrm{~nm}$, the AHP amplitude was reduced by $>1.0 \mathrm{mV}$ in CA1 neurons from both young (1.18 \pm $0.30 \mathrm{mV} ; p<0.003)$ and aging $(1.17 \pm 0.27 \mathrm{mV} ; p<0.001)$ subjects (Fig. 6, Table 3). The integrated area of the AHP was significantly reduced for CA1 neurons from both age groups $(p<$ 0.009 for young; $p<0.005$ for aging). The duration of the AHP was also significantly shortened for CA1 neurons from aging subjects $(p<0.034)$, and a trend for such a reduction was observed in young $(p>0.106)$.

Accommodation was significantly reduced in CA1 neurons from both age groups. In CA1 neurons from aging subjects, the number of action potentials elicited by a long depolarizing pulse was nearly doubled after carbachol (500 nM) application ( $p=$ 0.0002). The effect on accommodation in CA1 neurons of young subjects was not nearly as dramatic, although it was significantly reduced, $(p=0.0010$; Fig. 6 , Table 3$)$. This may be caused by the fact that the baseline accommodation was stronger in CA1 neu- 


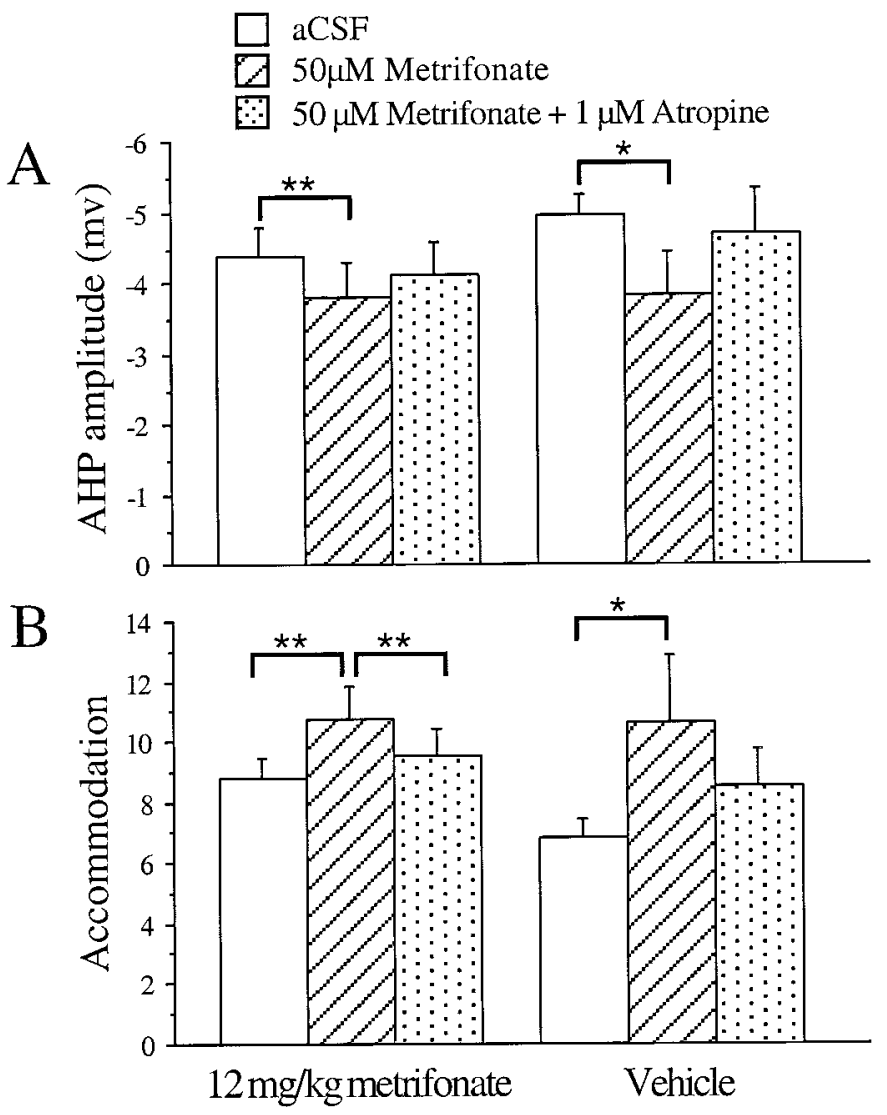

Figure 5. Bath application of $50 \mu \mathrm{M}$ metrifonate significantly decreased the AHP peak amplitude $(A)$ and increased the number of action potentials elicited during the accommodation pulse $(B)$ in CA1 neurons from both the chronically metrifonate- and vehicle-treated, aging subjects. The decrease in accommodation was significantly reversed by addition of $1 \mu \mathrm{M}$ atropine to the perfusate for the CA1 neurons from metrifonate-treated, aging subjects (mean $\pm \mathrm{SEM} ;{ }^{*} p<0.05$; ${ }^{*} p<0.01$; paired $t$ tests).

rons of aging subjects $\left(F_{(1,23)}=6.19 ; p<0.021\right)$ (Moyer et al., 1992).

\section{Eserine increased neuronal excitability}

The cholinesterase inhibitor eserine significantly decreased the AHP and spike frequency accommodation in CA1 neurons from young subjects in a manner similar to that previously reported (Cole and Nicoll, 1984a,b; Halliwell 1990). The AHP peak amplitude was significantly reduced when 1 or $5 \mu \mathrm{M}$ eserine was added to the perfusate $(p<0.007 ; p<0.018$, respectively; Table $3)$. The accommodation was significantly decreased for all concentrations of eserine tested ( $p$ values $<0.01$; Table 3 ). Also, the input resistance was similarly increased with a significant effect observed for $1 \mu \mathrm{M}$ eserine $(p<0.018)$.

\section{No significant changes were observed with time}

Normal aCSF was used as one of the blind perfusates on CA1 neurons from young and aging subjects to determine possible neuronal deterioration over time in the recording chamber (Table 3). No significant changes were observed in CA1 neurons from either young or aging subjects over time.

\section{DISCUSSION}

The present set of experiments revealed that (1) bath-applied metrifonate significantly increases neuronal excitability in vitro;
(2) chronic metrifonate treatment increases the basal level of neuronal excitability ex vivo; (3) neurons from chronically metrifonate-treated subjects remain sensitive to bath application of metrifonate, i.e., no "saturating" effect is observed with chronic treatment; and (4) the excitability changes observed with metrifonate mimic that observed with the cholinergic agonist carbachol and the cholinesterase inhibitor eserine, and could be reversed by atropine, thus metrifonate acts primarily via muscarinic cholinergic neurotransmission.

A higher concentration of metrifonate was necessary to significantly increase the neuronal excitability of CA1 neurons of aging rabbits compared with that of the young (Fig. 2, Table 1). This suggests an apparent shift in the efficacy of metrifonate for the neurons of aging rabbits. Likewise, a ceiling effect of metrifonate (tested up to $200 \mu \mathrm{M}$ ) was not observed in the neurons from aging rabbits. In the neurons from young rabbits, $100 \mu \mathrm{M}$ metrifonate depolarized the neurons with high-frequency bursts of action potentials, leading to membrane potential instability and eventual cell death. However, no such effects were observed in the neurons from aging rabbits. If anything, a greater reduction of AHP and accommodation was observed with higher concentration of metrifonate in the neurons from aging rabbits. One possible contributing factor to these effects may be the reduced level of endogenous ACh in vivo in aging subjects (Scali et al., 1997; Vannucchi et al., 1997), which may translate into less endogenous ACh present in the tissue of aging subjects in vitro. Scali and colleagues (1997) report that $80 \mathrm{mg} / \mathrm{kg}$ of metrifonate given to young and aging rats produced unequal increase in ACh levels in the hippocampus in vivo: a threefold increase in the young compared with only a $30 \%$ increase in the aged. Thus, a higher dose of metrifonate may be needed to allow cholinergic reduction of the larger AHPs and stronger accommodations that are generally observed in CA1 neurons from aging subjects (see Results; Landfield and Pitler, 1984; Moyer et al., 1992).

Chronic metrifonate treatment caused a clear reduction of RBC AChE inhibition similar to the effect previously reported by Kronforst-Collins et al. (1997b). CA1 neurons from the metrifonate-treated rabbits were found to be more excitable, resembling neurons from the young rabbits. Furthermore, the AHP and accommodation of neurons from chronically metrifonate-treated rabbits remained sensitive to the bath application of metrifonate (Fig. 4). This observation is consistent with the results obtained by Hinz et al. (1998) that chronic metrifonate treatment did not (1) alter the ACh synthesis rate, (2) change the muscarinic or nicotinic receptor binding, or (3) affect the monoamines in the brain (Soininen et al., 1990). This is contrary to the effects of chronic treatment with tacrine, which increased dopaminergic and serotoninergic metabolism (Soininen et al., 1990) and decreased binding to high-affinity choline uptake and nicotinic and muscarinic receptors (Sihver et al., 1997).

Numerous experiments have examined the modulatory role of cholinergic inputs in various learning and memory tasks, especially in aging subjects. For example, experiments with the central cholinergic blocker, scopolamine, demonstrated that humans (Solomon et al., 1993) and rabbits (Harvey et al., 1983) were impaired in learning delay (nonhippocampus-dependent) eyeblink conditioning when pretreated with scopolamine. This impairment is hypothesized to be mediated by the hippocampus, because scopolamine treatment did not impair hippocampal-lesioned subjects from acquiring delay eyeblink conditioning (Solomon et al., 1983), but did prevent rabbits from acquiring trace (hippocampus-dependent) eyeblink conditioning (Kaneko and 


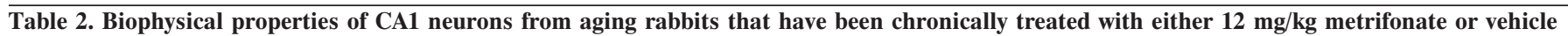

\begin{tabular}{|c|c|c|c|c|c|c|}
\hline & \multirow[b]{2}{*}{$n$} & \multicolumn{3}{|c|}{ Postburst afterhyperpolarization } & \multirow{2}{*}{$\begin{array}{l}\text { Accommodation (\# of } \\
\text { action potentials) }\end{array}$} & \multirow{2}{*}{$\begin{array}{l}\text { Input resistance } \\
(\mathrm{M} \Omega)\end{array}$} \\
\hline & & Amplitude (mV) & Area (mVsec) & Duration (sec) & & \\
\hline \multicolumn{7}{|l|}{$12 \mathrm{mg} / \mathrm{kg}$ metrifonate } \\
\hline $\mathrm{aCSF}$ & 19 & $-4.38 \pm 0.41$ & $-3.87 \pm 0.59$ & $2.82 \pm 0.35$ & $8.76 \pm 0.71$ & $42.46 \pm 2.57$ \\
\hline Metrifonate $(50 \mu \mathrm{M})$ & 14 & $-3.80 \pm 0.49$ & $-3.18 \pm 0.58$ & $2.69 \pm 0.42$ & $10.75 \pm 1.10$ & $51.86 \pm 2.33$ \\
\hline \multicolumn{7}{|l|}{ Metrifonate $(50 \mu \mathrm{M})$} \\
\hline+ Atropine $(1 \mu \mathrm{M})$ & 15 & $-4.12 \pm 0.47$ & $-3.72 \pm 0.61$ & $3.31 \pm 0.35$ & $9.45 \pm 0.91$ & $43.13 \pm 2.62$ \\
\hline \multicolumn{7}{|l|}{ Vehicle } \\
\hline $\mathrm{aCSF}$ & 28 & $-4.70 \pm 0.34$ & $-4.81 \pm 0.70$ & $3.16 \pm 0.25$ & $6.40 \pm 0.40$ & $44.94 \pm 1.95$ \\
\hline Metrifonate $(50 \mu \mathrm{M})$ & 17 & $-4.15 \pm 0.47$ & $-4.19 \pm 0.88$ & $3.31 \pm 0.43$ & $9.02 \pm 0.93$ & $47.53 \pm 2.31$ \\
\hline \multicolumn{7}{|l|}{ Metrifonate $(50 \mu \mathrm{M})$} \\
\hline+ Atropine $(1 \mu \mathrm{M})$ & 13 & $-4.78 \pm 0.51$ & $-5.25 \pm 1.21$ & $3.82 \pm 0.42$ & $7.37 \pm 0.67$ & $42.12 \pm 4.26$ \\
\hline
\end{tabular}

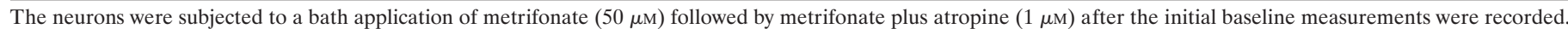

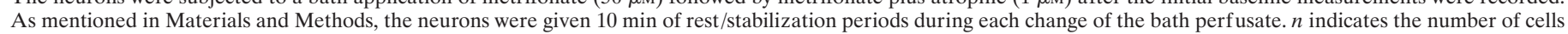
recorded. The measurements are the mean \pm SEM.

Thompson, 1997). Treatment with metrifonate reversed the deficits observed in acquiring the passive and active avoidance, Morris water maze, and radial-arm maze tasks by normal aging, medial-septum lesioned, or scopolamine-treated subjects (Riekkinen et al., 1996, 1997; van der Staay et al., 1996; Itoh et al., 1997; Dachir et al., 1997). Also, in double-blind clinical trials, metrifonate treatment alleviated the cognitive impairments observed in AD patients with minimal side-effects (Cummings et al., 1998; Morris et al., 1998; Pettigrew et al., 1998).

We hypothesize that the increased neuronal excitability described here underlies the learning enhancement we have observed with chronic metrifonate treatment in aging rabbits (Kronforst-Collins et al., 1997a,b). The reductions of the AHP and accommodation are of particular significance because they are well correlated with learning (Moyer et al., 1996; Thompson et al., 1996b). Both are reduced in hippocampal neurons from rabbits that acquire the trace eyeblink conditioning task, but not in the control animals or in animals that are trained but fail to acquire the task (Disterhoft et al., 1996; Moyer et al., 1996; Thompson et al., 1996b). The AHP and accommodation changes also parallel the time course of hippocampal function. The hippocampus is required for the acquisition, but not long-term recall, of trace eyeblink conditioning (Kim et al., 1995). Changes in neuronal excitability were observed immediately after acquisition, and the neuronal changes returned to that of the controls (presumed basal levels) within $7 \mathrm{~d}$, whereas the behavioral performance remained asymptotic for months (Moyer et al., 1996; Thompson et al., 1996b). By that time memory storage was presumably mediated through the neocortex and/or associated circuitry. Similar results were obtained with the L-type calcium channel blocker, nimodipine, providing further support for this neuronal excitability hypothesis. Nimodipine facilitated acquisition of trace eyeblink conditioning and increased neuronal excitability (reduced the AHP and accommodation) (Deyo et al., 1989; Moyer et al., 1992; Kowalska and Disterhoft, 1994). This is similar to the situation that we find here with chronic metrifonate treatment: enhanced acquisition rate of trace eyeblink conditioning, tightly coupled with increased CA1 excitability ex vivo.

The importance of cholinergic modulation of synaptic transmission in the hippocampus and neocortex during learning and recall of novel associations have been emphasized by Hasselmo et al. (1992), Hasselmo and Bower (1992), and Hasselmo and Schnell (1994). They posit that the learning rate is increased and

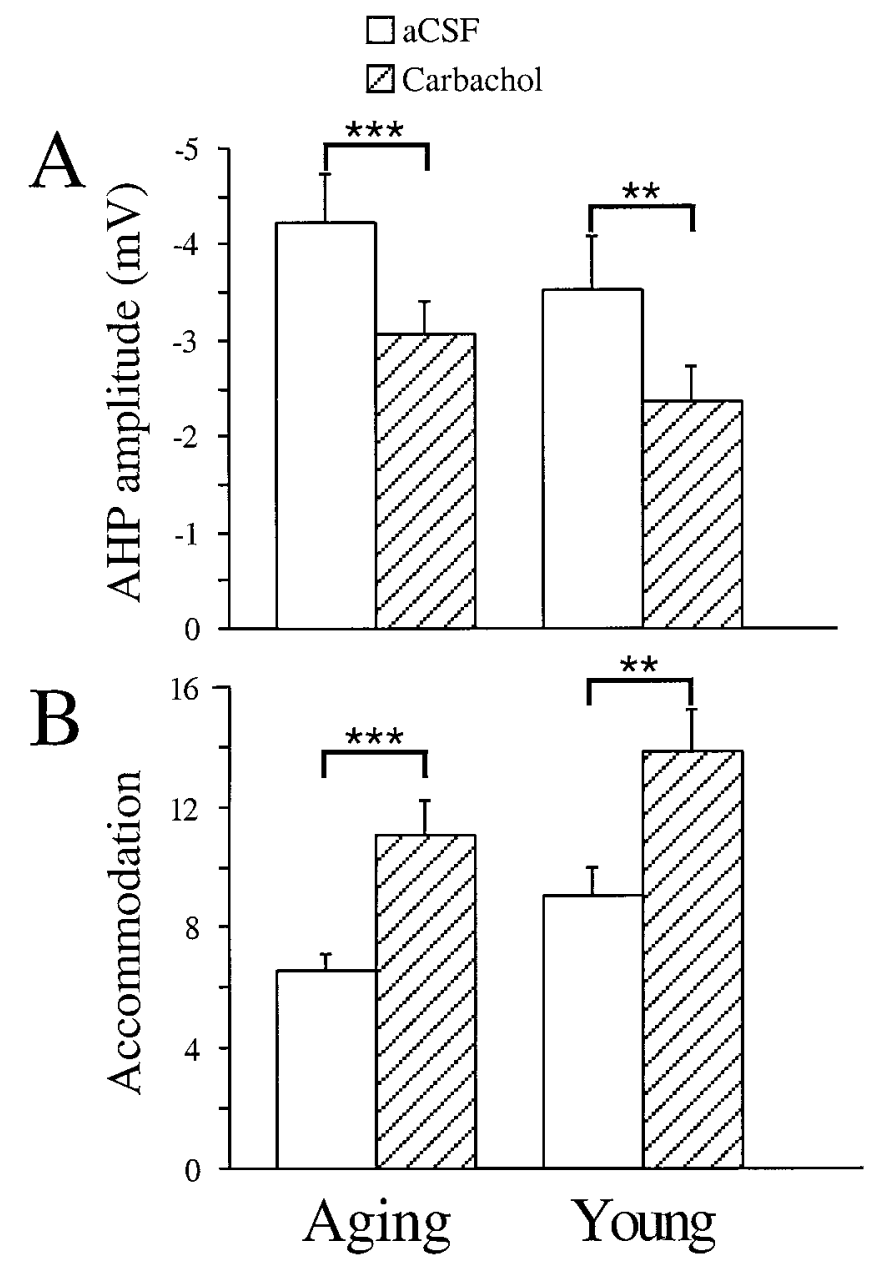

Figure 6. Bath application of $500 \mathrm{~nm}$ carbachol significantly increased CA1 excitability in neurons from both young and aging subjects. The mean AHP peak amplitude was significantly reduced by $500 \mathrm{~nm}$ carbachol (striped bars) as compared with the baseline (open bars) measurements $(A)$. The mean accommodation was significantly reduced by $500 \mathrm{~nm}$ carbachol (striped bars) as compared with the baseline (open bars) measurements $(B)$ (mean $\pm \mathrm{SEM} ;{ }^{* *} p<0.01 ;{ }^{* * *} p<0.001$; paired $t$ tests). 
Table 3. Mean change of biophysical properties of CA1 neurons from young and aging rabbits after bath application of carbachol, eserine, atropine, or aCSF in vitro

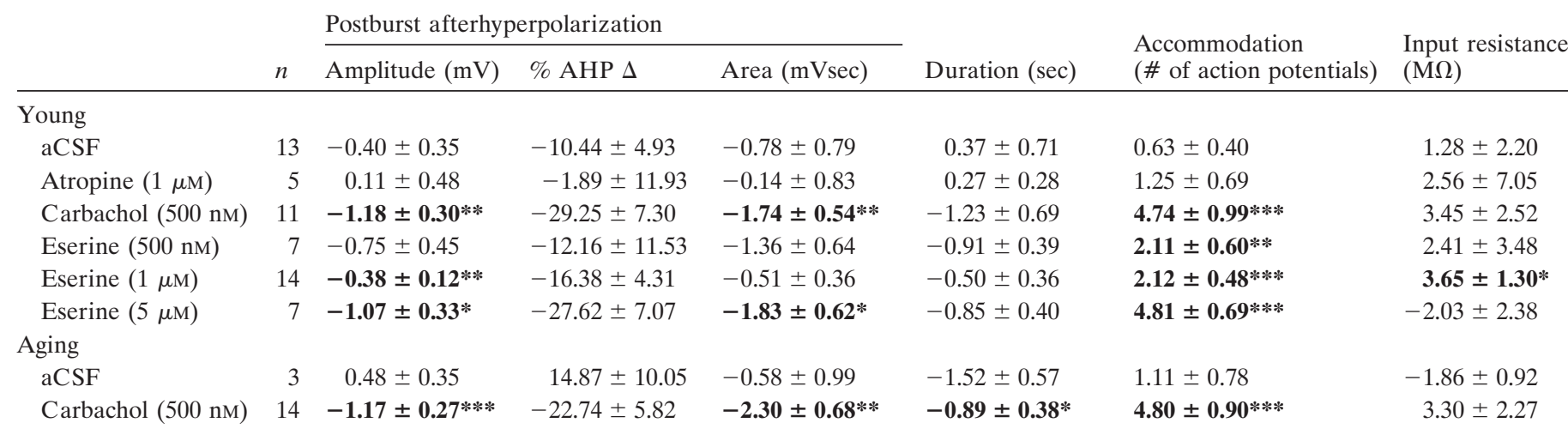

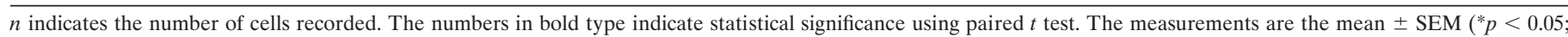
${ }^{* *} p<0.01 ; * * * p<0.001$; paired $t$ tests).

the maintenance of memory is prolonged by cholinergic suppression of the intrinsic fiber synapses in the hippocampus and cortex during learning. They further postulate that there is a direct regulation of $\mathrm{ACh}$ concentration in the hippocampus: during learning of new associations, the cholinergic input is high; during recall of learned associations, the cholinergic input is low (Hasselmo and Schnell, 1994). Their hypotheses of the cholinergic modulation fits very well with what may be occurring in the hippocampus of rabbits during trace eyeblink conditioning. As the rabbits are initially learning to associate the tone with the airpuff (novel association), the cholinergic input into the hippocampus would be increased, thereby increasing the neuronal excitability of the pyramidal neurons (AHP and accommodation reductions). This boost of increased neuronal excitability with ACh may be crucial for aging rabbits (that are usually impaired in learning the trace eyeblink conditioned response) (Thompson et al., 1996a) to learn associative tasks: slow EPSPs and CA1 population EPSPs are significantly reduced in aging subjects compared with the young (Landfield et al., 1986; Barnes et al., 1992; Potier et al., 1992; Taylor and Griffith, 1993). Soon after acquiring the tone-airpuff association, the cholinergic input to the hippocampus would begin to decrease, but the neuronal excitability of the pyramidal neurons would remain increased for a period of time (Moyer et al., 1996; Thompson et al., 1996b). With the steady decline of the cholinergic input to the hippocampus, the neuronal excitability of the pyramidal neurons would return to the basal state. But the association would be maintained over time, because by that point the memory for the association would have been stored in the neocortex, as rabbits tested months after the training sessions perform asymptotically on trace eyeblink conditioning (Moyer et al., 1996; Thompson et al., 1996b). In the behavioral experiments conducted by Kronforst-Collins et al. (1997b), metrifonate treatment clearly facilitated acquisition of trace eyeblink conditioning and decreased AChE activity (thus, increased ACh throughout the brain) in aging rabbits. After acquiring the task and after metrifonate treatment was ceased, the metrifonatetreated rabbits still displayed asymptotic behavior (KronforstCollins et al., 1997b), suggesting that the cholinergic input was important for acquisition but not the recall of the association.

Recently, Zhang et al. (1997) have demonstrated that AChE inhibition led to an increased (as long as $30 \mathrm{sec}$ ) temporal "window" for ACh to modulate the current underlying the slow AHP $\left(I_{\mathrm{sAHP}}\right)$ (i.e., reduce the AHP) in CA1 neurons in vitro after a train of cholinergic afferent stimulation in CA1 stratum radiatum; without the AChE inhibitors, the window was $<5$ sec. They further speculated that the window may be shorter in vivo. They have also demonstrated that the stimulation of the cholinergic afferents must precede the CA1 depolarization (activity) by 400 $1500 \mathrm{msec}$ to achieve the $I_{\text {sAHP }}$ reduction (Zhang et al., 1996). It is possible that metrifonate in vivo increases the ACh level in the synapses of pyramidal neurons, prolonging the temporal window for ACh modulation of pyramidal neuronal activity and resulting in an increased signal-to-noise ratio that facilitates the acquisition of various behavioral tasks in aging and cholinergic-deficient (AD and medial-septal or scopolamine lesioned) subjects. In trace eyeblink conditioning, where a stimulus-free trace period separates the conditioned and unconditioned stimuli, the AChE inhibition should increase the ACh present in the synapses of hippocampal pyramidal neurons during the trace period. This would help the subject to associate the conditioned and unconditioned stimuli and enhance the acquisition rate in aging subjects.

In summary, the increased neuronal excitability (as evidenced by the reduced postburst afterhyperpolarization and spike frequency adaptation) of hippocampal pyramidal neurons may be one of the underlying mechanisms by which the hippocampus stores information during associative learning. As previously demonstrated, the AHP and accommodation are reduced in hippocampal neurons when a subject learns an associative task but not in subjects that did not learn the same associative task (Moyer et al., 1996; Thompson et al., 1996b). Furthermore, the AHP and accommodation are greater in neurons from aging subjects than from the young (Landfield and Pitler, 1984; Moyer et al., 1992); in the same aging population, a severe impairment in learning associative tasks (such as trace eyeblink conditioning) is observed (Thompson et al., 1996a). The learning deficit observed in the aging population is alleviated by pharmacological agents, such as metrifonate (Kronforst-Collins et al., 1997a,b) and the L-type calcium channel blocker nimodipine (Deyo et al., 1989; Kowalska et al., 1994). These same two compounds have been demonstrated to increase hippocampal pyramidal neuronal excitability (reduced AHP and accommodation) in vitro (see results and Moyer et al., 1992). Thus, increased neuronal excitability of hippocampal pyramidal neurons may be one mechanism by which memory is transiently stored in the hippocampus during the early stages of learning before being transferred to the neocortex for 
more permanent storage. Pharmacological agents that cause an excitability increase comparable to that which occurs during the acquisition process in young subjects appear to enhance learning in normal aging subjects and perhaps in those undergoing a neurodegenerative process such as Alzheimer's disease.

\section{REFERENCES}

Aghajanian GK, Rasmussen K (1989) Intracellular studies in the facial nucleus illustrating a simple new method for obtaining viable motoneurons in adult rat brain slices. Synapse 3:331-338.

Barnes CA, Rao G, Foster TC, McNaughton BL (1992) Region-specific age effects on AMPA sensitivity: electrophysiological evidence for loss of synaptic contacts in hippocampal field CA1. Hippocampus 2:457-468.

Bartus RT, Dean RL III, Beer B, Lippa AS (1982) The cholinergic hypothesis of geriatric memory dysfunction. Science 217:408-417.

Becker RE, Moriearty P, Unni L (1991) The second generation of cholinesterase inhibitors: clinical and pharmacological effects. In: Cholinergic basis for Alzheimer therapy (Becker RE, Giacobini E, eds), pp 263-296. Boston: Birkhauser.

Bernardo LS, Prince DA (1981) Acetylcholine induced modulation of hippocampal pyramidal neurons. Brain Res 211:227-234.

Bernardo LS, Prince DA (1982) Cholinergic excitation of mammalian hippocampal pyramidal cells. Brain Res 249:315-331.

Cole AE, Nicoll RA (1983) Acetylcholine mediates a slow synaptic potential in hippocampal pyramidal cells. Science 221:1299-1301.

Cole AE, Nicoll RA (1984a) Characterization of a slow cholinergic post-synaptic potential recorded in vitro from rat hippocampal pyramidal cells. J Physiol (Lond) 352:173-188.

Cole AE, Nicoll RA (1984b) The pharmacology of cholinergic excitatory responses in hippocampal pyramidal cells. Brain Res 305:283-290.

Coulter DA, LoTurco JJ, Kubota M, Disterhoft JF, Moore JW, Alkon DL (1989) Classical conditioning reduces amplitude and duration of calcium-dependent afterhyperpolarization in rabbit hippocampal pyramidal cells. J Neurophysiol 61:971-981.

Cummings JL, Cyrus PA, Bieber F, Mas J, Orazem J, Gulanski B, and the Metrifonate Study Group (1998) Metrifonate treatment of the cognitive deficits of Alzheimer's Disease. Neurology 50:1214-1221.

Dachir S, Schmidt B, Levy A (1997) Effects of metrifonate on radial-arm maze acquisition in middle-aged rats. Brain Res 777:251-254.

de Jonge MC, Black J, Deyo RA, Disterhoft JF (1990) Learninginduced afterhyperpolarization reductions in hippocampus are specific for cell type and potassium conductance. Exp Brain Res 80:456-462.

Deyo RA, Straube KT, Disterhoft JF (1989) Nimodipine facilitates associative learning in aging rabbits. Science 243:809-811.

Disterhoft JF, Coulter DA, Alkon DL (1986) Conditioning-specific membrane changes of rabbit hippocampal neurons measured in vitro. Proc Natl Acad Sci USA 83:2733-2737.

Disterhoft JF, Golden DT, Read HL, Coulter DA, Alkon DL (1988) AHP reductions in rabbit hippocampal neurons during conditioning correlate with acquisition of the learned response. Brain Res 462:118-125.

Disterhoft JF, Thompson LT, Moyer Jr JR, Mogul DJ (1996) Calciumdependent afterhyperpolarization and learning in young and aging hippocampus. Life Sciences 59:413-420.

Hallak M, Giacobini E (1989) Physostigmine, tacrine and metrifonate: the effect of multiple doses on acetylcholine metabolism in rat brain. Neuropharmacology 26:521-530.

Halliwell JV (1990) Physiological mechanisms of cholinergic action in the hippocampus. Prog Brain Res 84:255-272.

Harvey JA, Gormezano I, Cool-Hauser VA (1983) Effects of scopolamine and methylscopolamine on classical conditioning of the rabbit's nictitating membrane response. J Pharmacol Exp Ther 225:42-49.

Hasselmo ME, Bower JM (1992) Cholinergic suppression specific to intrinsic not afferent fiber synapses in rat piriform (olfactory) cortex. J Neurophysiol 67:1222-1229.

Hasselmo ME, Schnell E (1994) Laminar selectivity of the cholinergic suppression of synaptic transmission in rat hippocampal region CA1: computational modeling and brain slice physiology. J Neurosci 14:3898-3914

Hasselmo ME, Anderson BP, Bower JM (1992) Cholinergic modulation of cortical associative memory function. J Neurophysiol 67:1230-1246.

Hinz VC, Kolb J, Schmidt BH (1998) Effects of subchronic administra- tion of metrifonate on cholinergic neurotransmission in rats. Neurochem Res 23:933-940.

Itoh A, Nitta A, Katono Y, Usui M, Naruhashi K, Iida R, Hasegawa T, Nabeshima T (1997) Effects of metrifonate on memory impairment and cholinergic dysfunction in rats. Eur J Pharmacol 322:11-19.

Kaneko T, Thompson RF (1997) Disruption of trace conditioning of the nictitating membrane response in rabbits by central cholinergic blockade. Psychopharmacology 131:161-166.

Kim JJ, Clark RE, Thompson RF (1995) Hippocampectomy impairs the memory of recently, but not remotely, acquired trace eyeblink conditioned responses. Behav Neurosci 109:195-203.

Kowalska M, Disterhoft JF (1994) Relation of nimodipine dose and serum concentration to learning enhancement in aging rabbits. Exp Neurol 127:159-166.

Kronforst-Collins MA, Moriearty PL, Ralph M, Becker RE, Schmidt B, Thompson LT, Disterhoft JF (1997a) Metrifonate treatment enhances acquisition of eyeblink conditioning in aging rabbits. Pharmacol Biochem Behav 56:103-110.

Kronforst-Collins MA, Moriearty PL, Schmidt B, Disterhoft JF (1997b) Metrifonate improves associative learning and retention in aging rabbits. Behav Neurosci 111:1031-1040.

Landfield PW, Pitler TA (1984) Prolonged $\mathrm{Ca}^{2+}$-dependent afterhyperpolarizations in hippocampal neurons of aged rats. Science 226:1089-1092.

Landfield PW, Pitler TA, Applegate MD (1986) The effects of high $\mathrm{Mg}^{2+}$-to- $\mathrm{Ca}^{2+}$ ratios on frequency potentiation in hippocampal slices of young and aged rats. J Neurophysiol 56:797-811.

Madison DV, Nicoll RA (1984) Control of the repetitive discharge of rat CA1 pyramidal neurones in vitro. J Physiol (Lond) 354:319-331.

Morris J, Cyrus PA, Orazem J, Mas J, Bieber F, Ruzicka BB, Gulanski B (1998) Metrifonate benefits cognitive, behavioral, and global function in patients with Alzheimer's disease. Neurology 50:1222-1230.

Moyer Jr JR, Thompson LT, Black JP, Disterhoft JF (1992) Nimodipine increases excitability of rabbit CA1 pyramidal neurons in an age- and concentration-dependent manner. J Neurophysiol 68:2100-2109.

Moyer Jr JR, Thompson LT, Disterhoft JF (1996) Trace eyeblink conditioning increases CA1 excitability in a transient and learning-specific manner. J Neurosci 16:5536-5546.

Nordgren I, Bergstrom M, Holmstedt B, Sandoz M (1978) Transformation and action of metrifonate. Arch Toxicol 41:31-41.

Pedarzani P, Storm JF (1996) Evidence that Ca/calmodulin-dependent protein kinase mediates the modulation of the $\mathrm{Ca}^{2+}$-dependent $\mathrm{K}^{+}$ current, $\mathrm{I}_{\mathrm{AHP}}$, by acetylcholine, but not by glutamate, in hippocampal neurons. Pflügers Arch 431:723-728.

Pettigrew LC, Bieber F, Lettier J, Wermeling DP, Schmitt FA, Tikhtman AJ, Ashford JW, Smith CD, Wekstein DR, Markesbery WR, Orazem J, Ruzicka BB, Mas J, Gulanski B (1998) A study of the pharmacokinetics, pharmacodynamics and safety of metrifonate in Alzheimer's disease patients. J Clin Pharmacol 38:236-245.

Potier B, Rascol O, Jazat F, Lamour Y, Dutar P (1992) Alterations in the properties of hippocampal pyramidal neurons in the aged rat. Neuroscience 48:793-806.

Riekkinen M, Schmidt B, Kuitunen J, Riekkinen Jr P (1997) Subchronic treatment increases the duration of the cognitive enhancement induced by metrifonate. Eur J Pharmacol 338:105-110.

Riekkinen Jr P, Schmidt B, Stefanski R, Kuitunen J, Riekkinen M (1996) Metrifonate improves spatial navigation and avoidance behavior in scopolamine-treated, medial septum-lesioned and aged rats. Eur J Pharmacol 309:121-130.

Scali C, Giovannini MG, Bartolini L, Prosperi C, Hinz V, Schmidt B, Pepeu G (1997) Effect of metrifonate on extracellular brain acetylcholine and object recognition in aged rats. Eur J Pharmacol 325:173-180.

Schmidt BH, Hinz VC, van der Staay FJ (1998) The preclinical pharmacology of metrifonate, a long-acting and well tolerated cholinesterase inhibitor for Alzheimer therapy. In: Progress in Alzheimer's and Parkinson's diseases (Fisher A, Yoshida M, Hanin J, eds), pp. 579-586. New York: Plenum.

Sihver W, Gunther P, Schliebs R, Bigl V (1997) Repeated administration of tacrine to normal rats: effects on cholinergic, glutamatergic, and GABAergic receptor subtypes in rat brain using receptor autoradiography. Neurochem Int 31:693-703.

Soininen H, Unni L, Shillcutt S (1990) Effect of acute and chronic cholinesterase inhibition on biogenic amines in rat brain. Neurochem Res 15:1185-1190.

Solomon PR, Solomon SD, Vander Schaaf ER, Perry HE (1983) Al- 
tered activity in the hippocampus is more detrimental to conditioning than removal of the structure. Science 220:329-331.

Solomon PR, Groccia-Ellison M, Flynn D, Mirak J, Edwards KR, Dunehew A, Stanton ME (1993) Disruption of human eyeblink conditioning after central cholinergic blockade with scopolamine. Behav Neurosci 107:271-279.

Taylor L, Griffith WH (1993) Age-related decline in cholinergic synaptic transmission in hippocampus. Neurobiol Aging 14:509-515.

Thompson LT, Moyer Jr JR, Disterhoft JF (1996a) Trace eyeblink conditioning in rabbits demonstrates heterogeneity of learning ability both between and within age groups. Neurobiol Aging 17:619-629.

Thompson LT, Moyer Jr JR, Disterhoft JF (1996b) Transient changes in excitability of rabbit CA3 neurons with a time course appropriate to support memory consolidation. J Neurophysiol 76:1836-1849.

van der Staay FJ, Hinz VC, Schmidt BH (1996) Effects of metrifonate on escape and avoidance learning in young and aged rats. Behav Pharmacol 7:56-64.

Vannucchi MG, Scali C, Kopf SR, Pepeu G, Casamenti F (1997) Selective muscarinic antagonists differentially affect in vivo acetylcholine release and memory performances of young and aged rats. Neuroscience 79:837-846.

Woodruff-Pak DS, Thompson RF (1988) Classical conditioning of the eyeblink response in the delay paradigm in adults aged 18-83 years. Psychol Aging 3:219-229.

Zhang L, Han D, Carlen PL (1996) Temporal specificity of muscarinic synaptic modulation of the $\mathrm{Ca}^{2+}$-dependent $\mathrm{K}^{+}$current $\left(\mathrm{I}_{\mathrm{sAHP}}\right)$ in rat hippocampal neurones. J Physiol (Lond) 496:395-405.

Zhang Y, Carlen PL, Zhang L (1997) Kinetics of muscarinic reduction of $\mathrm{I}_{\mathrm{SAHP}}$ in hippocampal neurons: effects of acetylcholinesterase inhibitors. J Neurophysiol 78:2999-3007. 